\title{
Front Matter: Volume 6668
}

, "Front Matter: Volume 6668," Proc. SPIE 6668, Novel Optical Systems Design and Optimization X, 666801 (26 September 2007); doi:

10.1117/12.773419

SPIE Event: Optical Engineering + Applications, 2007, San Diego, California, United SPIE. States 


\section{PROCEEDINGS OF SPIE}

\section{Novel Optical Systems Design and Optimization $X$}

R. John Koshel

G. Groot Gregory

Editors

28-29 August 2007

San Diego, California, USA

Sponsored and Published by

SPIE

Volume 6668 
The papers included in this volume were part of the technical conference cited on the cover and title page. Papers were selected and subject to review by the editors and conference program committee. Some conference presentations may not be available for publication. The papers published in these proceedings reflect the work and thoughts of the authors and are published herein as submitted. The publisher is not responsible for the validity of the information or for any outcomes resulting from reliance thereon.

Please use the following format to cite material from this book:

Author(s), "Title of Paper," in Novel Optical Systems Design and Optimization X, edited by R. John Koshel, G. Groot Gregory, Proceedings of SPIE Vol. 6668 (SPIE, Bellingham, WA, 2007) Article CID Number.

ISSN 0277-786X

ISBN 9780819468161

Published by

SPIE

P.O. Box 10, Bellingham, Washington $98227-0010$ USA

Telephone +1 3606763290 (Pacific Time) · Fax +1 3606471445

SPIE.org

Copyright (c) 2007, Society of Photo-Optical Instrumentation Engineers

Copying of material in this book for internal or personal use, or for the internal or personal use of specific clients, beyond the fair use provisions granted by the U.S. Copyright Law is authorized by SPIE subject to payment of copying fees. The Transactional Reporting Service base fee for this volume is $\$ 18.00$ per article (or portion thereof), which should be paid directly to the Copyright Clearance Center (CCC), 222 Rosewood Drive, Danvers, MA 01923. Payment may also be made electronically through CCC Online at copyright.com. Other copying for republication, resale, advertising or promotion, or any form of systematic or multiple reproduction of any material in this book is prohibited except with permission in writing from the publisher. The CCC fee code is $0277-786 \mathrm{X} / 07 / \$ 18.00$.

Printed in the United States of America.

Publication of record for individual papers is online in the SPIE Digital Library.

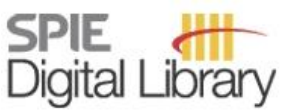

SPIEDigitalLibrary.org

Paper Numbering: Proceedings of SPIE follow an e-First publication model, with papers published first online and then in print and on CD-ROM. Papers are published as they are submitted and meet publication criteria. A unique, consistent, permanent citation identifier (CID) number is assigned to each article at the time of the first publication. Utilization of CIDs allows articles to be fully citable as soon they are published online, and connects the same identifier to all online, print, and electronic versions of the publication. SPIE uses a six-digit CID article numbering system in which:

- The first four digits correspond to the SPIE volume number.

- The last two digits indicate publication order within the volume using a Base 36 numbering system employing both numerals and letters. These two-number sets start with $00,01,02,03,04,05$, $06,07,08,09,0 \mathrm{~A}, 0 \mathrm{~B} \ldots \mathrm{OZ}$, followed by 10-1Z, 20-2Z, etc.

The CID number appears on each page of the manuscript. The complete citation is used on the first page, and an abbreviated version on subsequent pages. Numbers in the index correspond to the last two digits of the six-digit CID number. 


\section{Contents}

vii Conference Committee
ix Introduction

\section{SESSION 1 OPTICAL DESIGN}

666802 Direct methods for freeform surface design (Invited Paper) [6668-02]

R. A. Hicks, Drexel Univ. (USA)

666803 Automated transfer of optical tolerances from CAD programs to optical codes [6668-03] M. S. Boren, R. C. Juergens, Raytheon Missile Systems (USA)

666804 Optical modeling activities for NASA's James Webb Space Telescope (JWST): IV. Overview and introduction of MATLAB based toolkits used to interface with optical design software [6668-04]

J. M. Howard, NASA Goddard Space Flight Ctr. (USA)

666805 Wavefront and caustic surfaces of refractive laser beam shaper [6668-05]

D. L. Shealy, Univ. of Alabama at Birmingham (USA); J. A. Hoffnagle, IBM Almaden

Research Ctr. (USA)

\section{SESSION 2 'REDUCED' OPTICS}

666806 Broadband endoscopic imaging through a single fiberoptic channel [6668-07]

A. Kano, College of Optical Sciences, Univ. of Arizona (USA) and Univ. of Arizona (USA); J. Koshel, College of Optical Sciences, Univ. of Arizona (USA); A. F. Gmitro, College of Optical Sciences, Univ. of Arizona (USA) and Univ. of Arizona (USA)

666807 Arc-section annular folded optic imager (Invited Paper) [6668-08]

E. Tremblay, Univ. of California, San Diego (USA); R. Stack, R. Morrison, Distant Focus Corp. (USA); J. Ford, Univ. of California, San Diego (USA)

666808 A study of LED light-linear device for light guide plate applications [6668-09]

C.-H. Chien, Z.-P. Chen, Tatung Univ. (Taiwan)

\section{SESSION 3 OPTICS EDUCATION I}

666809 Creating scientific and technical talent through educational outreach [6668-10] D. E. Diggs, J. G. Grote, J. Fielding, Air Force Research Lab. (USA); K. W. Jones, L. C. Jenkins, Aeronautical Systems Ctr., U.S. Air Force (USA); I. L. Turner, Freescale Semiconductor, Inc. (USA) 
6668 OA Professional development in photonics: the advanced technology education projects of the New England Board of Education (Invited Paper) [6668-11]

J. Donnelly, Three Rivers Community College (USA); F. Hanes, New England Board of Higher Education (USA); N. Massa, Springfield Technical Community College (USA)

\section{SESSION 4 HISTORICAL PERSPECTIVES IN OPTICAL DESIGN}

6668 OB Evidence supporting the primacy of Joseph Petzval in the discovery of aberration coefficients and their application to lens design (Invited Paper) [6668-12]

A. Rakich, LBT Observatory (USA); R. Wilson, European Southern Observatory (Germany)

6668 OC The earliest history of computer-aided optical design on large computers: the previously classified work by James G. Baker 1945-1954 (Invited Paper) [6668-13]

K. P. Thompson, Optical Research Associates (USA)

\section{SESSION 5 OPTICS EDUCATION II}

6668 OD Hands-on optics: an informal science education initiative [6668-14]

A. M. Johnson, Univ. of Maryland, Baltimore County (USA); S. M. Pompea, National Optical Astronomy Observatory (USA); E. G. Arthurs, SPIE (USA); C. E. Walker, R. T. Sparks, National Optical Astronomy Observatory (USA)

$6668 \mathrm{OE}$ Teaching lens, optical systems, and opto-mechanical systems design at the Irvine Center for Applied Competitive Technologies (CACT) [6668-15]

V. V. Doushkina, MetroLaser, Inc. (USA) and Optics Institute of Southern California (USA);

D. M. Silberman, Optics Institute of Southern California (USA), Physik Instrumente L.P. (USA), and Irvine Ctr. for Applied Competitive Technologies (USA)

6668 OF A course in illumination engineering [6668-16]

R. J. Koshel, Lambda Research Corp. (USA) and College of Optical Sciences, The Univ. of Arizona (USA)

$66680 \mathrm{O}$ Art + technology in optics educational outreach programs [6668-17]

D. M. Silberman, Optics Institute of Southern California (USA) and Physik Instrumente L.P. (USA)

$6668 \mathrm{OH}$ Finding science is fun in a 'Magic Show of Light' from Optical Demonstrations on an Overhead Projector for elementary school students [6668-18]

J. J. Lones, Adroit Engineering (USA); N. K. Maltseva, St. Petersburg State Univ. of Information Technologies, Mechanics and Optics (Russia); K. N. Peterson, Clarenceville School District Board of Education (USA)

\section{SESSION 6 OPTICAL SYSTEMS AND APPLICATIONS}

6668 Ol High numerical aperture line scanning system [6668-19]

R. Liang, Carestream Health, Inc. (USA) 
$6668 \mathrm{OJ}$ Space imaging optical guidance for ground vehicle [6668-20]

A. Akiyama, Kanazawa Technical College (Japan); N. Kobayashi, Kanazawa Institute of Technology (Japan); E. Mutoh, Kawasaki Heavy Industries Ltd. (Japan); H. Kumagai, Tamagawa Seiki Co., Ltd. (Japan); H. Yamada, Kanazawa Technical College (Japan); H. Ishii, Nihon Univ. (Japan)

6668 OK Volume holographic beam splitter for hyperspectral imaging applications [6668-21]

J. D. Matchett, R. I. Billmers, E. J. Billmers, M. E. Ludwig, RL Associates, Inc. (USA)

$6668 \mathrm{OL}$ A dual channel lens for simultaneous VIS and SWIR imaging in harsh radiation environments [6668-22]

S. Dets, Mattson Technology Canada (Canada) and resOptica Technologies (Canada)

\section{SESSION 7 OPTICS FOR MOBILE SYSTEMS}

6668 0N Design issues for semi-passive optical communication devices [6668-25]

I. Glaser, Holon Institute of Technology (Israel)

666800 Micro-lens maker equation of a CMOS image sensor [6668-26]

Y. Wu, OmniVision Technologies, Inc. (USA)

6668 OP Zoom lens design of mobilephone camera with global-explorer optimization [6668-28]

C.-Y. Hung, J.-L. Chern, National Chiao-Tung Univ. (Taiwan)

\section{POSTER SESSION}

$66680 Q \quad$ The study of diffraction optical element applied to resonant cavity LED [6668-24]

S.-H. Chang, Far East Univ. (Taiwan); T.-C. Liang, H.-S. Huang, National Kaohsiung First Univ. of Science and Technology (Taiwan)

6668 OR Variable focus photographic lens without mechanical movements [6668-30]

J. Chen, R. Peng, S. Zhuang, Univ. of Shanghai for Science and Technology (China)

6668 OS Structural design of a lens component with prespecified aberration targets by evolutionary algorithm [6668-32]

S. Chatterjee, L. N. Hazra, Univ. of Calcutta (India)

6668 OT Novel microscopy in arbitrary step digital holography [6668-33]

C.-Y. Lin, National Central Univ. (Taiwan); G.-L. Chen, M.-K. Kuo, National Defense Univ. (Taiwan); C.-C. Chang, Ming Dao Univ. (Taiwan); H.-F. Yau, National Central Univ. (Taiwan)

6668 OU The design of a noble VCSEL with DOE [6668-34]

T.-C. Liang, National Kaohsiung First Univ. of Science and Technology (Taiwan); S.-H. Chang, Far East Univ. (Taiwan); H.-S. Huang, National Kaohsiung First Univ. of Science and Technology (Taiwan)

$66680 \mathrm{~V}$ Innovative global approach for high-performance low-cost integral field unit (IFU) [6668-35]

S. Vivès, E. Prieto, Lab. d'Astrophysique de Marseille (France); Y. Salaun, Winlight Optics (France) 
6668 OW Design of a wavelength-tunable light source using an acousto-optic tunable filter [6668-37] H. Hall, M. Bridges, Carestream Health, Inc. (USA); S. Leavesley, J. P. Robinson, Purdue Univ. (USA)

Author Index 


\title{
Conference Committee
}

\author{
Conference Chairs
}

R. John Koshel, Lambda Research Corporation (USA) and College of Optical Sciences, The University of Arizona (USA)

G. Groot Gregory, Optical Research Associates (USA)

Program Committee

Jyh-Long Chern, National Chiao Tung University (Taiwan)

Alexander Epple, Carl Zeiss AG (Germany)

Joseph M. Howard, NASA Goddard Space Flight Center (USA)

Richard C. Juergens, Raytheon Missile Systems (USA)

Scott A. Lerner, Hewlett-Packard Company (USA)

Rongguang Liang, Carestream Health, Inc. (USA)

Andrew B. Locke, ZEMAX Development Corporation (USA)

Paul K. Manhart, ASML (USA)

Richard N. Pfisterer, Photon Engineering, LLC (USA)

Andrew Rakich, LBT Observatory (USA)

Jannick P. Rolland, College of Optics \& Photonics, University of Central Florida (USA)

José M. Sasian, The University of Arizona (USA)

David L. Shealy, The University of Alabama, Birmingham (USA)

Donn M. Silberman, PI Physik Instrumente L.P. (USA), Optics Institute of Southern California (USA), and Irvine Center for Applied

Competitive Technologies (USA)

Marija Strojnik-Scholl, Centro de Investigaciones en Óptica, A.C. (Mexico)

Kevin P. Thompson, Optical Research Associates (USA)

Mary G. Turner, Breault Research Organization, Inc. (USA)

Session Chairs

1 Optical Design

Jannick P. Rolland, College of Optics \& Photonics, University of Central Florida (USA)

2 'Reduced' Optics

Joseph M. Howard, NASA Goddard Space Flight Center (USA) 
Donn M. Silberman, PI Physik Instrumente L.P. (USA), Optics Institute of Southern California (USA), and Irvine Center for Applied

Competitive Technologies (USA)

$4 \quad$ Historical Perspectives in Optical Design

G. Groot Gregory, Optical Research Associates (USA)

5 Optics Education II

Donn M. Silberman, PI Physik Instrumente L.P. (USA), Optics Institute of Southern California (USA), and Irvine Center for Applied Competitive Technologies (USA)

R. John Koshel, Lambda Research Corporation (USA) and College of Optical Sciences, The University of Arizona (USA)

$6 \quad$ Optical Systems and Applications

Andrew Rakich, LBT Observatory (USA)

$7 \quad$ Optics for Mobile Systems

Rongguang Liang, Carestream Health, Inc. (USA) 


\section{Introduction}

This year in San Diego, California, we held the Tenth Conference of Novel Optical Systems Design and Optimization. The conference was well attended, with papers ranging from optical design to education and history to mobile optics. This year there were seven oral sessions and one poster session. The primary focus of the conference was "reduced optics" and optics education. The seven oral sessions had the following titles: optical design, 'reduced' optics, optics education I and II, historical perspective in optical design, optical systems and applications, and optics for mobile systems. These oral sessions ranged over one and a half days of the entire 2007 Optics and Photonics Symposium.

The conference started with a session of optical design, presenting such topics as freeform surfaces for imaging design, $C A D$ and mathematical analysis software integration into optical codes, and laser beam shaping. The next session on reduced optics presented how to reduce the size of an optical system while maintaining performance. This year there were two sessions on optics education ranging the whole gamut from primary school to graduate education, continuing education, and outreach. Sandwiched between the two education sessions was a session on the history of optical design. On the second day were two sessions. The first presented specific optical systems and how they were applied to solve challenging problems such as imaging in harsh radiation environments. Novel optical system design and optimization ended with three papers on mobile optics - i.e., optical systems in cell phones and smart cards.

There were a number of invited papers over the duration of the conference:

- A discussion by Andrew Hicks from Drexel University about direct method for determining freeform imaging surfaces;

- A paper given by Eric Tremblay of the University of California, San Diego, about the ability to fold optical systems in an arc-sectioned annual pattern to reduce the overall length of the optical system (see paper 6668-08);

- Judy Donnelly of Three Rivers Community College gave a paper on professional development in photonics, with a project under the auspices of the New England Board of Education funded by the National Science Foundation;

- A history talk by Andrew Rakich of EOS Space Systems about Joseph Petzval and how he may have been the originator of aberration theory, and;

- A second history talk by Kevin Thompson of Optical Research Associates about the classified optical design of James Baker in the 40s and 50s. He was the first user of large computers for such work. 
As can be seen, the invited topics covered a large range of the field of optical design and engineering. It indicates that the optical design community is still working on challenging problems, and also that the range of fields calling on optical engineering is increasing. This breadth led to lively and interesting discussions following each paper. Additionally, these discussions were carried into the hallways following each session. In conclusion, the Novel Optical Systems Design and Optimization Conference continues building upon previous years. It is expected that next year's conference will maintain this growth.

Our thanks go to those who helped make this conference a success, especially the authors, audience, SPIE staff, and program committee. The authors alone made this conference an unqualified success. The audience built upon this success by being active and asking engaging questions. The SPIE staff ensured that everything ran smoothly before, during, and after the meeting. The program committee provided excellent assistance to ensure the quality of the content while also presiding over a number of the sessions. It was composed of Jyh-Long Chern, Alexander Epple, Joseph Howard, Scott Lerner, Rongguang Liang, Andrew Locke, Paul Manhart, Richard Pfisterer, Andrew Rakich, Jannick Rolland, Jose Sasian, David Shealy, Donn Silbermann, Marija Strojnik-Scholl, Kevin Thompson, and Mary Turner.

Next year we will return for the eleventh iteration of this conference. The chairs will remain for only one more iteration as Groot Gregory and John Koshel - at least one new chair will be part of the twelfth Novel Optical Conference. The planning for Novel Optical Systems Design and Optimization XI in 2008 is already underway, so please start planning submissions, questions, and attendance. The planned focus topics are optical design with software post-processing of the images, a look back and forward at zoom systems, and liquid optics. If you would like to assist with the 2008 or later conference please contact one of us. We look forward to seeing you in 2008 !

\section{R. John Koshel G. Groot Gregory}

